$11,337(48 \%)$ of the women were known to have istopped taking the pill, 7,563 $(32 \%)$ were lost or withdrawn, and only 4,711 (20\%) were known to be still taking the pill at the time of the final analysis. The main reason given for stopping the pill was intercurrent morbidity (33.6\%). This was mostly depression and headaches. However, it is stated, "the report shows that only in a small fraction of these diseases is there any convincing evidence that the pill has any adverse pharmacological influence, and the justification for stopping in other circumstances must be questioned." Only 7.1\% stcpped for side effects which were unspecified.

In the C.I.F.C. trial of 797 women receiving one or more of 34 oral contraceptives over six years we found that "women found oral contraceptives so efficient and beneficial that few discontinued the method unless they had multiple complaints. These were headaches, mood changes, vein changes, irregular cycles and weight gain." The number stopping the pill within a year related closely to the number with headaches and the number whose endometnial biopsies showed prominent arterioles. For several progestogen-oestrogen combinations a critical dose level was found which produced a maximum effect on headaches and endometrial anterioles, and this peak effeot was very sensitive to small changes in either oestrogen or progestogen. In view of these findings it is odd to say that headache is unlikely to be a pharmacological side effect of the pill and that the increase is affected by excess reponting and substantial bias.

The report dismisses the studies showing a significant increase of depression and an association of progestogen use as being "less well controlled than those with a more favourable conclusion." Our finding of $28 \%$ of depression and loss of libido with strongly progestogenic low-aestrogen pills and $6^{\circ}$ with the strongly oestnogenic pills was supponted by the matching changes in monoamine oxidase activity in the endometrium. ${ }^{4}$ There is now strong evidenoe $e^{5-7}$ in suppont of our earlier findings that depression and loss of libido are due to hormone and enzyme changes. In the same C.I.F.C. trial vein complaints, leg oramps, and thrombophlebitis were significantly more frequent with the combined pills containing a relanively low dose of progestogen and a high dose of oestrogen than with the other groups tested, and the clinical symptoms correlated with changes in endometrial sinusoids. ${ }^{3}$

There are many other criticisms that could be levelled against the report, but it is important as it highlights the large numbers of conditions made worse by the pill in a short time and shows an increase in the deaths when the large number of drop-outs are taken into account. As it was supported by so much public money, it is unfontunate that the general public has been given a winong impression of what the report does show. A close look at it does not give the reassurance of the pill's advantages compared with other methods of contraception implied by the press coverage, and there is no reason to think doctors need not be on the look-out for warning symptoms of disease which can lead to irreversible changes.-I am, etc.,

New Malden, Surrey

ELLEN C. G. Grant

1 Royal College of General Practitioners, Oral Con traceptives and Health. London, Pitman Medical, traceptiv

2 Grant, E. C. G., British Medical fournal, 1968, 3, 402.
4,73. 7 . C. G., British Medical fournal, 1969,

Grant, E. C. G., and Pryse-Davies, J., British Medical fournal, 1968, 3, 777 .

Wyatt, D. L., and Murphy, R. G., Science, 1973, 173, 916.

Coppin, A., Eccleston, E. G., and Peet. M.,

A Linar, $197,2,60$

tions System, 1973, 1, July, p. 30 .

\section{Achalasia of the Cardia}

SIR,-Your leading anticle on this subject (8 June, p. 515) rightly stresses the impontance of early treatment. In the very early stages of the disease stripping waves may be seen in the oesophagus at a barium swallow examination which are more forceful than normal waves, but they are rendered ineffective because the distal sphincter does not relax. As the condition progresses the stripping waves diminish until eventually they may disappear. It has never been established whether the loss of stripping waves is secondary to the dilatation and obstruotion of the oesophagus or whether it is a part of the disease itself.

If the condition is treated early enough the oesophagus never dilates and is able to empty with the patient lying. It is not, perhaps, as widely known as it should be that the presence of stripping waves does not refute the diagnosis of early achalasia. -I am, etc.,

Cambridge

F. R. BERRIDGE

\section{Salaries in Occupational Medicine}

SIR,-Doctors working in occupational medicine will note that new recommended salary scales have been approved and are now published (see p. 130).

These new scales are in line with the in creases recommended for doctors in the N.H.S. by the Review Body. They are within stage three and may legally be paid by employers back-dated to 1 April 1974 provided that the 12-month rule is observed. They do not, however, include threshold payments since these cannot be paid unless threshold agreements have been made.

Some large industries fix their doctors' salaries in discussions with the B.M.A. and these employers have, of course, been asked to make the appropriate inoreases; they have
The rules about threshold agreemen Thicated and so an explanation is included with every copy of the new salary scales (which are appended to the booklet "The Doctor in Industry" obtainable from the Secretary of the B.M.A.). The important point, however, is that doctors should try to make a threshold agreement as soon as possible because payment is lawful only if the agreement is made before the monthly cost of living figures are announced.-I am etc.

$$
\begin{array}{r}
\text { R. E. W. FISHER } \\
\text { Occupairman, } \\
\text { Octional Health Committee, B.M.A. }
\end{array}
$$

B.M.A. House,

\section{Clinical Public Health Doctors and} Community Medicine

SIR,-Your leading article (18 May, p. 348) rightly stresses the curnent uncertainty of the clinical medical officers. As more Ministry circulars are published the links of the previous clinical public health doctors with community medicine are becoming more uncertain. An alarming fact is that the Faculty of Community Medicine seems to have turned its face against all preventive clinical work as not being part of the work of the community physician.

It is obvious that Ministry and regional medical officers are totally administrative and this is largely true for the area medical officer. When the duties of the specialists in community medicine and the district community physician are considered, though there is a large administrative responsibility, the contact with the patient is potentially greater. However, Ministry teams travel the country and inform us that clinical work is no part of the role of the consultant in community medicine. There must be no reduction in preventive servioes to the patient and it is hopefully assumed that there are enough clinical medical officers left to continue this work.

To consider two illustrations of the dilemma. I submit that the community specialists in child health with no interest in clinical work will have poor advice to offer in their responsibilities to the education authorities. Similarly the specialists in community medicine (environmental health) need an up-to-date clinical knowledge to control infectious disease adequately.

It seems to me that at district and area levels a small but significant part of the work of the community physician is clinical in content and is thus complementary to the work of the clinical doctors, who are nic lenger in "public health" but in "community msdicine"-it is well to remember that many of these clinical doctors are members of the Faculty of Community Medicine. Thus the clinical preventive work should be fostered

All of us await the Court Report with interest, and 12 months to two years is a long time to wait. In the meantime clinical medical officers remain in their state of uncertainty. The school health service and other preventive clinical services are enfeebled in those industrial areas where the service is needed most. Am I too cynical in suggesting that perhaps some management expert somewhere has decided that the child health service has had its day? Personally, I do not think careful assessment of childnen is ever a waste of time and I trust that this aspect at least will be preserved in the future. However, we had better hurry and decide on the career struoture for the clinical doctors, or by the time the decision has been taken at top management level the older clinical 
doctors will have retired, and there will be no young enthusiasts from the medical schools in clinical preventive health.-I am etc.,

Wirral, Merseyside

PHILIP Nicholas

\section{Review Body Report}

SIR,-The Review Body yet again has failed to recagnize the worsening plight of the G.P.s. Patients are getting better care and more of it, while the G.P.s' expenses rise and their incomes fall way behind those of other professional groups. It has reached the point where standards must fall. We need strong leadership from the B.M.A. to correct this exploitation of doctors and the inevitable drift of doctors abroad.-We are, etc.,

$$
\begin{aligned}
\text { N. GORDON } & \text { J. MCCARTHY } \\
\text { J. V. THOMAS } & \text { M. ROY BAIN } \\
\text { RICHARD WILSON } & \text { S. DHATT }
\end{aligned}
$$

Langley, Bucks

SiR,-Consultants-especially whole - time, with no alternative source of income and completely at the mercy of the monopoly employer-will gain small comfort from the sympathetic noises made by the Review Body while recommending a rise of what amounts to roughly $£ 200$ a year, net of tax.

Lord Halsbury's dismissal of the much higher levels of consultant remuneration in other countries as irrelevant appears to reflect a very parochial attitude. It is very far from irrelevant, as we have already discovered here to our cost. In this department we have had an unfilled consultant vacancy for over six months. A suitable candidate, with British specialist qualification and experience, at present working in Holland, applied for the post but later turned it down when he worked out the full financial implications of moving. In Holland he is being paid roughly three times the salary he would get here. Another possible candidate has decided to take a consultant post in the Antipodes and two other "possibles" have deoided to go to Canada-largely because of the much higher scale of remuneration there. The younger consultants are already "voting with their feet" and who can blame them? If we accept-as we apparently must -the restraints of phase three of the Government's wages and income policy, the Review Body could at least have indicated the level of awards it would have recommended in the absence of the pay code.

If the consultants cannot look immediately for any more generous treatment where pay is concerned, there is one way in which they could be helped and that is through income tax relief on depreciation of their motor cars. General practitioners get up to $80 \%$; it is a glaring anomaly that consultants get nothing but a somewhat niggardly mileage allowance. We have to spend at least $£ 1,000$ every three to four years in replacing the car, which is used predominantly, by most consultants, in the hospital service. Tax allowance on this depreciation would do something to redress the balance between consultants and general practitioners.-I am, etc.,
SIR,-I believe all clinical public health medical officers will be feeling very angry on reading the summary of recommendations of the Review Body (Supplement, 29 June, p. 124). Just when we thought we were at last to be considered and paid in the same way as other members of our profession we are told that no proposals are made for us. We have to await discussions by the Health Departments and the profession, and a future review-presumably in summer 1975. Promises do not compensate for the ever-rising cost of living. I think this must bring morale and recruitment in the clinical medical officer field to a very low level. Those of us who have given many years to this work are wondering for how much longer we can 'tolerate being the Cinderellas of the medical profession.-I am etc.

Liverpool

J. PHILLIPS

SIR,-The Secretary's letter "The Review Body and You" should be read in conjunction with Peter Jay's warnings on inflationary pnospects in The Times. ${ }^{1} \mathrm{He}$ says: "The warnings are not heard. If heard, they are not believed. If believed, they are not thought to apply to the special circumstances of the believer."

Like everyone else I should like my pay to be more and to be brought into line with that of comparable workers. After a medical career in different public services I find myself facing a pension of less than half the wages claimed by the miners. But, like the miners, we can have more money only at someone else's expense. To demand more money at this time of pending economic disaster is antisocial, is unchristian, is unpatriotic, and is just plain silly, and will lower the profession still further in public esteem. Moreover, any Government which gives way to us will deservedly lose votes.

Would it not be a worthwhile gesture if doctors were to offer to forgo the contemptibly small award of the Review Body and the inflationary threshold agreement on condition that members of Parliament impose oomparable cuts in their own salaries? Perhaps we could start a counterinflationary spiral. We have so little to lose that it is worth a try; success would do a great deal to efface the image of a money-grubbing profession and place us in a strong moral position when happier times make it more sensible to negotiate better pay and conditions for ourselves and other Health Service workers.

Will our negotiators make this conditional offer to the Government?-I am, etc.,

Eastleigh, Hants

MARK HUGHES

1 Jay, P., The Times, 1 July 1974, p. 14.

\section{G.P.s and Family Planning}

SIR,-The ordinary fee for contraceptive services as recommended by the Review Body has been set at a figure of $£ 1.72$ per annum. It has not been specified, however, which services will have to be provided in order to attract this fee. If the figure refers to a single annual consultation with counselling and presoription of an appropriate oral contraceptive, it would in my view be acceptable. If, however, it is a capitation payment designed to apply to an unlimited number of consultations required by the patient over a yearly period it should in my judgement be rejected as quite inadequate.

It has been recommended by various authorities that women who are taking an oral contraceptive should be examined every six months. The examination should include a history noting in particular the incidence of migraine and depressive features. This should be followed by estimation of blood pressure, examination of urine for detection of glycosuria, and examination of the lower limbs for evidence of thrombophlebitis. If this procedure is carried out every six months a fee of $£ 5$ per annum would not seem excessive. If the offer of $£ 1.72$ is meant to cover two such examinations and any further consultations requested by the patient it should be firmly rejected as yet another example of the undervaluing of our services by successive govennments. It is this policy and its acceptanoe by our profesion which has led to our position on the bottom rung of the economic ladder of Western Europe.-I am, etc.,

Hornchurch, Essex

D. D. CoWAN

\section{Reward for Effort}

SIR,-May I raise a few points in reply to Mr. W. Calvert (22 June, p. 674)?

The figure of $£ 9,000$ is surely the gross earnings of the general practitioner-that is, before deduction of practice expenses, which might amount to ome-thind of the gross income. This gives a figure not far from the average net earnings of general practitioners, which is about £5,500 per annum.

While it is true that until vocational uraining for general practice becomes mandatory a doctor may become an unrestricted pnincipal in general practice after only six months' experienœe sinœe full registration (or indeed after none), over $96 \%$ of G.P.s entering practice have had six months' or more postregistration experience and more than $50 \%$ have had at least three years' experience after full registration. ${ }^{1}$

Lastly, to what extent does financial rewand play an impontant pant in career choice? There seems little evidenoe that it does. While it may be argued that the increasing number of G.P.s from 1966 may be due to the increased financial rewands after the "chanter," the increase may be due to the increasing output of the medical schools or to an increasing awareness among dootors of the job satisfaction to be obtained in general practice. If financial considerations were paramount one might expect that the payments made to G.P.s to work in designated areas would have led to an increasing number of G.P.s in those areas. Despite the payments these areas remain under-doctoned. Some hospital specialties attract mone reoruits than others-for example, there is a "large surplus" of senior registrars in gynaeoology and obstetrics and a "lange deficit" in child psychiatry." This may be due partly to finanoial comsiderations -increased oppontunity for private practice and merit awards, perhaps-or partly to the image of the specialty in the minds of undergraduates and those recently qualified. It would seem, however, that despite the ad- 